\section{Ex Vivo Sentinel Lymph Nodes in Pathological Staging of Node-Negative Colorectal Carcinoma}

\section{TO THE EDITORS:}

Märkl et al. have highlighted a new concept for the histological role of ex vivo sentinel lymph nodes in nodenegative colorectal cancer. The rationale of sentinel lymph node mapping in colorectal cancer is to improve the sensitivity of histopathological evaluation by selective application of time-consuming, expensive, and sophisticated techniques, such as multistep sectioning, immunohistochemistry, and polymerase chain reaction. ${ }^{1}$

However, the last edition of the tumor, node, metastasis system (TNM) classification of malignant tumors should be considered. $^{2}$ This classifies as N1c the presence of tumor deposits ("satellites") in the pericolorectal adipose tissue's lymph drainage area of a primary colorectal carcinoma without histological evidence of a residual lymph node in the nodule and in the absence of regional lymph node metastases. This is the case unless the neoplastic nodule is considered by the pathologist to be a totally replaced lymph node and may be recorded as a positive lymph node and not as a satellite. The sentinel node procedure, apart from the rationale of improving the sensitivity of pathological evaluation or avoiding unnecessary nodal dissection, is not useful for the detection of satellites.

The ex vivo sentinel node procedure is an effective method for improving nodal staging in node-negative colorectal cancer by immunohistochemical detection of (micro)metastasis in sentinel lymph nodes. However, the presence of macroscopic or microscopic tumor deposits in pericolorectal adipose tissue is a not readily detectable discontinuous spread from the primary tumor that should be considered for complete TNM staging of node-negative tumors.

Nadia Peparini, MD, PhD, and Piero Chirletti, MD Department of General Surgery "Francesco Durante", La Sapienza University, Rome, Italy

e-mail: nadiapeparini@yahoo.it

Published Online: 11 November 2010

(C) Society of Surgical Oncology 2010

\section{REFERENCES}

1. Märkl B, Arnholdt HM, Jähnig H, et al. A new concept for the role of ex vivo sentinel lymph nodes in node-negative colorectal cancer. Ann Surg Oncol. 2010;17:2647-55.

2. Sobin LH, Gospodarowicz MK, Wittekind Ch, eds. TNM classification of malignant tumours. 7th ed. New York: Wiley-Blackwell, 2009. 